\title{
Recognition of Early Eocene global carbon isotope excursions using lipids of marine Thaumarchaeota
}

\author{
Petra L. Schoon ${ }^{\mathrm{a}, 1}$, Claus Heilmann-Clausen ${ }^{\mathrm{b}}$, Bo Pagh Schultz ${ }^{\mathrm{c}}$, Appy Sluijs ${ }^{\mathrm{d}}$, \\ Jaap S. Sinninghe Damsté ${ }^{\mathrm{a}, \mathrm{d}}$, Stefan Schouten ${ }^{\mathrm{a}, \mathrm{d}, *}$ \\ ${ }^{a}$ NIOZ Royal Netherlands Institute for Sea Research, Department of Marine Organic Biogeochemistry, P.O. Box 59, 1790 AB Den Burg, Texel, the Netherlands \\ ${ }^{\mathrm{b}}$ Aarhus University, Department of Geoscience, Høegh-Guldbergs Gade 2, 8000 Aarhus C, Denmark \\ ${ }^{\text {c }}$ Fur Museum, Nederby 28, 7884 Fur, Denmark \\ d Department of Earth Sciences, Faculty of Geosciences, Utrecht University, 43584 CD Utrecht, The Netherlands
}

\section{A R T I C L E I N F O}

\section{Article history:}

Received 15 October 2012

Received in revised form

24 April 2013

Accepted 25 April 2013

Editor: G. Henderson

Available online 27 May 2013

\section{Keywords:}

PETM

carbon isotope excursion

GDGTs

\begin{abstract}
A B S T R A C T
The Paleocene-Eocene Thermal Maximum (PETM; 56 Ma) and Eocene Thermal Maximum 2 (ETM2; $\sim 53 \mathrm{Ma}$ ) are geological short ( $<200,000$ years) episodes of extreme global warming and environmental change. Both the PETM and ETM2 are associated with the injection of ${ }^{13} \mathrm{C}$-depleted carbon into the ocean-atmosphere system as revealed through a globally recognized carbon isotope excursion (CIE) and massive dissolution of deep sea carbonate. However, the magnitude of these CIEs vary with the type of fossil matter, i.e. multiple carbonate phases, bulk organic matter, and terrestrial and marine biomarker lipids, making it difficult to constrain the actual CIE in atmospheric and oceanic carbon pools. Here we analyzed the stable carbon isotopic composition $\left(\delta^{13} \mathrm{C}\right)$ of glycerol dibiphytanyl glycerol tetraether lipids (GDGTs) derived from marine Thaumarchaeota in sediments deposited during the PETM in the North Sea Basin and ETM2 in the Arctic Ocean. The $\delta^{13} \mathrm{C}$ values of these lipids are potentially directly recording variations in $\delta^{13} \mathrm{C}$ dissolved inorganic carbon (DIC) and can thus provide a record of marine $\delta^{13} \mathrm{C}$ DIC across both these Eocene carbon cycle perturbations. Reconstructed pre-CIE $\delta^{13} C_{D I C}$ values are slightly lower $(0.5-1 \%$ ) than modern day values, possibly because Thaumarchaeotal lipids are not only derived from surface waters but also from ${ }^{13} \mathrm{C}$-depleted subsurface waters. Their values decrease by $\sim 3.6( \pm 0.3)$ $\%$ and $\sim 2.5( \pm 0.7) \%$ o during the PETM and ETM2, respectively. The CIE in crenarchaeol for ETM2 is higher than that in marine calcite from other locations, possibly because of the admixture of deep water ${ }^{13} \mathrm{C}$-depleted $\mathrm{CO}_{2}$ generated by the euxinic conditions that developed occasionally during ETM2. However, the reconstructed PETM CIE lies close to the CIE inferred from marine calcite, suggesting that the $\delta^{13} \mathrm{C}$ record of crenarchaeol may document changes in marine DIC during the PETM in the North Sea Basin. The $\delta^{13} \mathrm{C}$ of thaumarchaeotal lipids may thus be a novel tool to reconstruct the $\delta^{13} \mathrm{C}$ of DIC in sediments that are devoid of carbonates, but relatively rich in organic matter, such as shallow marine coastal settings.
\end{abstract}

(c) 2013 Elsevier B.V. All rights reserved.

\section{Introduction}

The Paleocene-Eocene Thermal Maximum (PETM) is characterized by a rapid large decrease in stable carbon isotope ratios $\left(\delta^{13} \mathrm{C}\right)$ in marine and terrestrial carbonates and organic matter and massive dissolution of seafloor carbonates, providing evidence for the massive and rapid injection of ${ }^{13} \mathrm{C}$-depleted carbon in the oceans and atmosphere (Dickens et al., 1997; Zachos et al., 2005;

\footnotetext{
* Corresponding author at: NIOZ Royal Netherlands Institute for Sea Research, Department of Marine Organic Biogeochemistry, P.O. Box 59, 1790 AB Den Burg, Texel, the Netherlands. Tel.: +31 22236 9565; fax: +31 222319674 .

E-mail address: stefan.schouten@nioz.nl (S. Schouten).

${ }^{1}$ Present address: Department of Earth Sciences-Biogeochemistry, University of California Riverside, 900 University Ave., Riverside, CA 92521, USA.
}

McInerney and Wing, 2011). Several mechanisms have been proposed to explain the global negative carbon isotope excursion (CIE), amongst others the release of thermogenic methane due to contact metamorphism (Svensen et al., 2004), rapid burning of terrestrial organic matter (Kurtz et al., 2003), the release of carbon stored in permafrost soils at high latitudes triggered by orbital forcing (DeConto et al., 2012), and the dissociation of methane hydrates (Dickens et al., 1995). Several of these hypotheses provide mechanisms that not only explain the CIE of the PETM, but also offer an explanation for the several smaller CIEs that have occurred after the PETM, such as the Eocene Thermal Maximum 2 (ETM2) and H2 event (Cramer et al., 2003; Lourens et al., 2005; Nicolo et al., 2007; Sluijs et al., 2009; Stap et al., 2010; Westerhold et al., 2009; Slotnick et al., 2012). However, authentication of the sources of the ${ }^{13} \mathrm{C}$-depleted carbon strongly depends on the 
magnitude of the actual CIE recorded in the PETM sediments (e.g., Pagani et al., 2006; Dickens, 2011). Unfortunately, the reported magnitude of the CIEs vary widely between different marine and terrestrial carbon records, such as carbonate shells, bulk organic matter and specific terrestrial and marine biomarkers (see Table 1 in McInerney and Wing, 2011). These variations in shape and magnitude of individual carbon isotope records are often caused through changes in: (1) the relative abundance of mixed components with different $\delta^{13} \mathrm{C}$ values within a measured substrate, (2) change in isotope fractionation through physiological change, and (3) the isotope composition of the carbon source, or combinations of these (Sluijs and Dickens, 2012 and references cited therein). Although the magnitude of the biases generated by these factors is relatively well known, assessing the magnitude of these biases for any individual $\delta^{13} \mathrm{C}$ record remains a challenge (Sluijs and Dickens, 2012).

In this study, we investigate the potential use of the stable carbon isotopic composition $\left(\delta^{13} \mathrm{C}\right)$ of the biomarker lipid crenarchaeol, which exclusively occurs in ammonia-oxidizing Thaumarchaeota (Pitcher et al., 2011 and references cited therein), to reconstruct the variations in $\delta^{13} \mathrm{C}$ of marine dissolved inorganic carbon (DIC), the largest carbon reservoir in the global exogenic carbon pool, during the Eocene hyperthermals. Several studies using ${ }^{13} \mathrm{C}$-labeling experiments and cultivation studies showed that Thaumarchaeota have a chemoautotrophic lifestyle (Jung et al., 2011; Park et al., 2010; Wuchter et al., 2003), using ammonium as electron donor, which is oxidized to nitrite (Hallam et al., 2006; Könneke et al., 2005; Wuchter et al., 2006). Based on the relatively ${ }^{13} \mathrm{C}$-enriched isotopic composition of crenarchaeol, and the isoprenoidal ether-bound lipids (biphytanes) derived thereof, compared to algal biomarkers, it was suggested that Thaumarchaeota take up bicarbonate as a carbon source (Hoefs et al., 1997; Pearson et al., 2001a; Kuypers et al.,
2001). Furthermore, Kuypers et al. (2001) found that the ${ }^{13} \mathrm{C}$ of the crenarchaeol was enriched by $3 \%$ compared to modern values during the mid-Cretaceous oceanic anoxic event $1 \mathrm{~b}$ and attributed this to the $2-3 \%$ o $\delta^{13} \mathrm{C}$ offset between modern and mid-Cretaceous DIC. Confirmation came from Berg et al. (2007), showing that Thaumarchaeota assimilate carbon through the 3-hydroxypropionate/4-hydroxybutyrate biochemical pathway, which involves the direct utilization of bicarbonate.

The active uptake of $\mathrm{HCO}_{3}{ }^{-}$by Thaumarchaeota suggests that the $\delta^{13} \mathrm{C}$ composition of Thaumarchaeal lipids may be independent to variations in $\mathrm{CO}_{2}$ concentrations, unlike phytoplankton (e.g. Laws et al., 1995), and predominantly depend on the $\delta^{13} \mathrm{C}$ of $\mathrm{HCO}_{3}{ }^{-}$. This is supported by labeling studies with enrichment cultures of marine Thaumarchaeota, which showed no limitation on growth rates of the Thaumarchaeota in response to increased aqueous $\mathrm{HCO}_{3}{ }^{-}$-levels (Park et al., 2010). Importantly, Könneke et al. (2012) found that the $\delta^{13} \mathrm{C}$ composition of both biomass as well as crenarchaeol of the Thaumarchaeote Nitrosopumilus maritimus was indeed independent of DIC concentrations, and the carbon isotopic fractionation between crenarchaeol and DIC was a consistent $-19.7 \pm 0.5 \%$. Interestingly, reported $\delta^{13} \mathrm{C}$ values of crenarchaeol in modern marine sediments range from $-18 \%$ o to $-23 \%$, average around $-21 \pm 1 \%$ (Schouten et al., 2013). Assuming that DIC of marine surface waters at the studied sites is roughly between $-1 \%$ and $1.5 \%$ (Kroopnick, 1985) and sedimentary crenarchaeol is mainly derived from pelagic sources (e.g. Schouten et al., 2010; Lengger et al., 2012), the $\delta^{13} \mathrm{C}$ values of crenarchaeol are thus fairly consistent with a fractionation of $\sim 20 \%$ as observed in $N$. maritimus. The $\delta^{13} \mathrm{C}$ composition of biphytanes derived from GDGTs produced by Thaumarchaeota may thus reflect changes in past $\delta^{13} \mathrm{C}$ values of marine DIC. This is a major advantage compared to other biomarker proxies reconstructing the $\mathrm{CIE}$ because bicarbonate comprises the largest carbon reservoir in the global exogenic carbon pool. Furthermore,

Table 1

Stable carbon isotope values of TOC and biphytanes for three PETM sections in Denmark and for the ETM2 section (IODP 302) from the Lomonosov Ridge, Arctic Ocean.

\begin{tabular}{|c|c|c|c|c|c|c|c|c|}
\hline \multirow[t]{2}{*}{ Sample code } & \multirow[t]{2}{*}{ Location } & \multirow[t]{2}{*}{ Age } & \multirow{2}{*}{$\begin{array}{l}\text { Depth } \\
(\mathrm{m})\end{array}$} & \multicolumn{5}{|c|}{ Stable carbon isotope composition $\left(\delta^{13} \mathrm{C}\right)$ in \% VPDB } \\
\hline & & & & TOC & BP-0 & BP-1 & BP-2 & BP-3 \\
\hline PS090785 & Fur, Denmark & CIE PETM & 30.51 & $-27.1 \pm 0.1$ & $-22.7 \pm 0.1$ & $-22.9 \pm 0.3$ & $-21.9 \pm 0.3$ & $-21.3 \pm 0.4$ \\
\hline PS090784 & Fur, Denmark & CIE PETM & 20.51 & $-29.8 \pm 0.1$ & $-25.2 \pm 0.1$ & $-24.4 \pm 0.2$ & $-22.8 \pm 0.5$ & $-22.5 \pm 0.4$ \\
\hline PS090783 & Fur, Denmark & CIE PETM & 17.51 & $-31.5 \pm 0.0$ & $-27.1 \pm 0.1$ & $-26.2 \pm 0.3$ & $-24.0 \pm 0.0$ & $-23.8 \pm 0.1$ \\
\hline PS090782 & Fur, Denmark & CIE PETM & 2.51 & $-30.8 \pm 0.1$ & $-28.3 \pm 0.3$ & $-25.9 \pm 0.2$ & $-25.5 \pm 0.2$ & $-25.1 \pm 0.2$ \\
\hline PS090781 & Fur, Denmark & CIE PETM & 1.06 & $-30.9 \pm 0.2$ & $-27.2 \pm 0.6$ & $-24.3 \pm 0.1$ & $-23.7 \pm 0.2$ & $-23.8 \pm 0.3$ \\
\hline PS090751 & Fur, Denmark & CIE PETM & 0.15 & $-31.0 \pm 0.1$ & $-27.2 \pm 0.5$ & $-24.5 \pm 0.2$ & $-23.5 \pm 0.2$ & $-23.4 \pm 0.1$ \\
\hline PS090750 & Fur, Denmark & CIE PETM & 0.08 & $-30.8 \pm 0.0$ & $-25.3 \pm 0.2$ & $-24.5 \pm 0.3$ & $-23.2 \pm 0.2$ & $-23.2 \pm 0.1$ \\
\hline PS090749 & Fur, Denmark & Latest Paleocene & -0.08 & $-25.9 \pm 0.2$ & $-25.7 \pm 0.2$ & $-31.5 \pm 0.1$ & $-22.1 \pm 0.3$ & $-21.1 \pm 0.3$ \\
\hline PS090748 & Fur, Denmark & Latest Paleocene & -0.16 & $-25.8 \pm 0.0$ & $-30.4 \pm 0.2$ & $-31.4 \pm 0.4$ & $-22.5 \pm 0.1$ & $-21.7 \pm 0.4$ \\
\hline PS090747 & Fur, Denmark & Latest Paleocene & -0.29 & $-26.7 \pm 0.0$ & $-26.2 \pm 0.1$ & $-26.6 \pm 0.2$ & $-22.4 \pm 0.3$ & $-21.6 \pm 0.2$ \\
\hline PS090790 & Ølst-Hinge, Denmark & Earliest Eocene & 9.27 & $-26.4 \pm 0.0$ & $-23.1 \pm 0.2$ & $-24.7 \pm 0.5$ & $-22.5 \pm 0.3$ & $-22.9 \pm 0.5$ \\
\hline PS090788 & Ølst-Hinge, Denmark & Earliest Eocene & 6.84 & $-27.2 \pm 0.0$ & $-22.3 \pm 0.3$ & -22.6 & $-21.7 \pm 0.2$ & $-21.5 \pm 0.3$ \\
\hline PS090787 & Ølst-Hinge, Denmark & Earliest Eocene & 4.52 & $-26.5 \pm 0.0$ & $-24.0 \pm 0.3$ & $-22.5 \pm 0.2$ & $-22.9 \pm 0.1$ & $-22.5 \pm 0.2$ \\
\hline PS090786 & Ølst-Hinge, Denmark & Earliest Eocene & 0.02 & $-27.0 \pm 0.0$ & $-24.3 \pm 0.3$ & $-20.0 \pm 0.2$ & $-21.0 \pm 0.1$ & $-20.4 \pm 0.2$ \\
\hline PS090789 & Ølst-Hinge, Denmark & CIE PETM & -1.20 & $-31.0 \pm 0.1$ & $-27.4 \pm 0.0$ & $-25.6 \pm 0.2$ & $-24.3 \pm 0.1$ & $-24.3 \pm 0.2$ \\
\hline PS090746 & Store Bælt, Denmark & CIE PETM & 128.45 & $-29.5 \pm 0.1$ & $-27.8 \pm 0.4$ & $-24.0 \pm 0.3$ & $-22.7 \pm 0.2$ & $-22.5 \pm 0.1$ \\
\hline PS105882 & Store Bælt, Denmark & CIE PETM & 129.27 & $-28.6 \pm 0.1$ & $-26.3 \pm 0.0$ & $-25.7 \pm 0.3$ & $-23.2 \pm 0.0$ & $-22.5 \pm 0.2$ \\
\hline PS090745 & Store Bælt, Denmark & CIE PETM & 130.89 & $-31.3 \pm 0.1$ & $-26.8 \pm 0.3$ & $-24.2 \pm 0.1$ & $-23.2 \pm 0.5$ & $-23.1 \pm 0.4$ \\
\hline PS103458 & Store Bælt, Denmark & CIE PETM & 131.85 & $-30.7 \pm 0.1$ & $-26.1 \pm 0.3$ & $-24.6 \pm 0.2$ & $-23.8 \pm 0.3$ & $-23.7 \pm 0.2$ \\
\hline $302-4-27 \times 1-59-60$ & Lomonosov Ridge, Arctic Ocean & Post-ETM2 & 367.99 & -29.1 & $-25.7 \pm 0.1$ & $-28.3 \pm 0.8$ & $-23.8 \pm 0.2$ & $-22.7 \pm 0.1$ \\
\hline $302-4-27 \times 1-118-120$ & Lomonosov Ridge, Arctic Ocean & CIE ETM2 & 368.58 & -29.3 & $-26.1 \pm 0.1$ & $-27.3 \pm 1.4$ & $-25.4 \pm 0.9$ & $-22.7 \pm 0.0$ \\
\hline $302-4-27 \times 1-122-124$ & Lomonosov Ridge, Arctic Ocean & CIE ETM2 & 368.62 & -29.8 & $-25.6 \pm 0.1$ & n.d. & n.d. & $-22.7 \pm 0.2$ \\
\hline $302-4-27 \times 1-132-134$ & Lomonosov Ridge, Arctic Ocean & CIE ETM2 & 368.72 & -30.8 & $-24.7 \pm 0.0$ & -25.5 & $-24.9 \pm 0.0$ & $-23.0 \pm 0.4$ \\
\hline $302-4-27 \times 1-139-141$ & Lomonosov Ridge, Arctic Ocean & CIE ETM2 & 368.79 & -31.2 & $-22.6 \pm 0.3$ & $-20.8 \pm 0.2$ & $-21.3 \pm 0.0$ & $-20.2 \pm 0.1$ \\
\hline $302-4-27 \times 2-12-14$ & Lomonosov Ridge, Arctic Ocean & CIE ETM2 & 369.00 & -27.5 & $-23.3 \pm 0.2$ & $-19.0 \pm 0.2$ & $-21.4 \pm 0.3$ & $-20.9 \pm 0.1$ \\
\hline $302-4-27 \times 2-31-32$ & Lomonosov Ridge, Arctic Ocean & Pre-ETM2 & 369.21 & -27.5 & $-23.0 \pm 0.4$ & $-21.0 \pm 0.1$ & $-20.4 \pm 0.2$ & $-19.5 \pm 0.3$ \\
\hline
\end{tabular}

n.d. $=$ not detected. 
since crenarchaeol is a unique biomarker lipid for marine Thaumarchaeota, the CIE in crenarchaeol should not be affected by mixing of different components with different $\delta^{13} \mathrm{C}$ values as with e.g. TOC.

To test this hypothesis, we analyzed the $\delta^{13} \mathrm{C}$ compositions of the biphytane moieties derived of archaeal GDGTs, obtained after ether-bond cleavage with $\mathrm{HI} / \mathrm{LiAlH}_{4}$, from sediment records spanning the PETM and ETM2 in the North Sea Basin and Arctic Ocean, respectively. We compare the $\delta^{13} \mathrm{C}$ values of the biphytanes with each other, in order to constrain sources of GDGTs and utilize the $\delta^{13} \mathrm{C}$ value of the biphytane specifically derived from crenarchaeol to reconstruct $\delta^{13} C_{\text {DIC }}$ across the Eocene hyperthermals.

\section{Materials and methods}

\subsection{Samples and sampling sites}

In this study, we used sediment samples that were previously used for other palynological and (organic) geochemical studies of the North Sea Basin PETM (Nielsen et al., 1986; Schmitz et al., 2004; Schoon, 2013) and Arctic Ocean ETM2 (Schoon et al., 2011; Sluijs et al., 2009) (Table 1). Sediments that cover the PaleoceneEocene transition are derived from three sites located in Denmark (Fig. 1). At time of deposition, Denmark was situated in the eastern part of the semi-enclosed, epicontinental, North Sea Basin. Two of the study sites are outcrops, of which one is located in the western Limfjorden area on the island Fur and the other is the Ølst-Hinge clay pit located in central Jutland. The third study site is an offshore section located in the sea strait Store Bælt cored in 1983 (Borehole no. 83101 carried out by the Danish Geotechnical Institute) in between the Danish islands Sjælland and Fyn (Nielsen et al., 1986). The PETM has been recognized at these sites on the basis of a negative $6-8 \%$ CIE in total organic carbon (TOC) and on the concomitant abundance peaks of dinocysts that belong to the organic-walled dinoflagellate cyst genus Apectodinium, including the species Apectodinium augustum, which is diagnostic of the PETM (Heilmann-Clausen and Schmitz, 2000; Schmitz et al.,

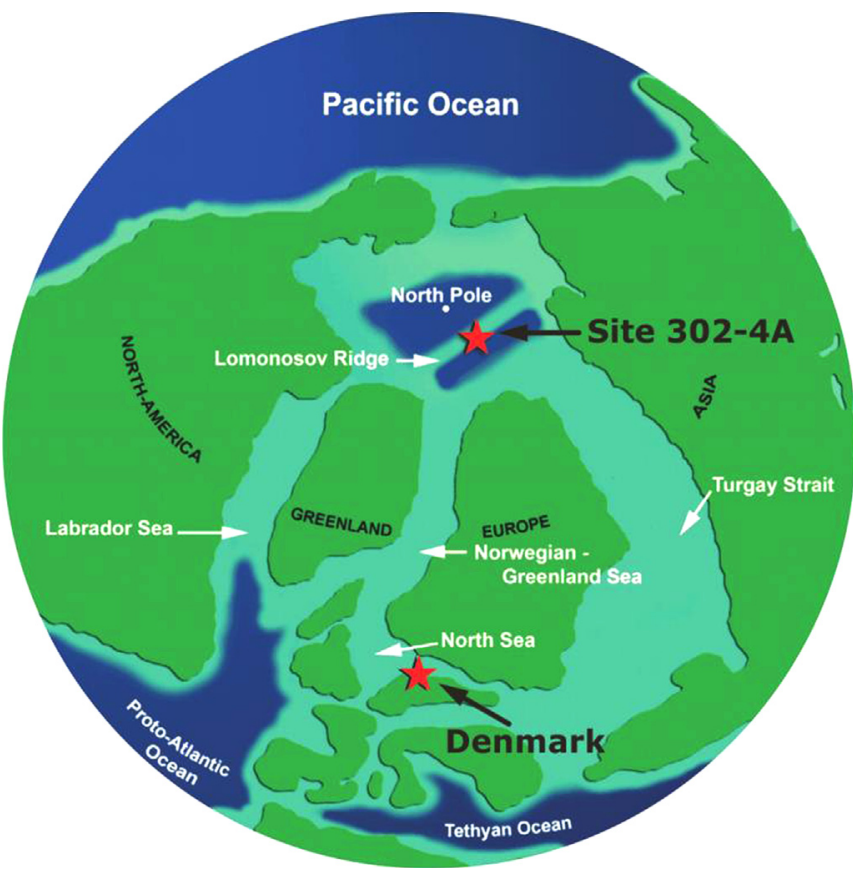

Fig. 1. Palaeogeographical map of the Late Paleocene and early Eocene showing the study locations of the PETM (Denmark) and ETM2 (Lomonosov Ridge). Adapted from Sluijs et al. (2009).
2004). The continuous section at Store Bælt records the entire CIE of the PETM. The Fur section, however, is interrupted by a glacially-disturbed interval of $10-20 \mathrm{~m}$ and possibly the maximum of the CIE of the PETM is missing (Schoon, 2013). The part of the Ølst-Hinge section studied here is a record of the earliest Eocene and includes the recovery phase of the CIE of the PETM.

Samples from ETM2 are derived from the Integrated Ocean Drilling Project (IODP) Hole 302-4 A, which was retrieved in 2004 (Backman et al., 2006). The site is located on the Lomonosov Ridge at $\sim 85^{\circ} \mathrm{N}$ palaeolatitude in the Central Arctic Ocean (O'Regan et al., 2008) (Fig. 1). This marine sedimentary sequence contains the ETM2 interval between 368.9 and $368.2 \mathrm{~m}$ composite depth (mcd) based on the $3.5 \%$ CIE in TOC and the presence of the dinocyst species Cerodinium wardenese and Hystrichosphaeridium tubiferum (Sluijs et al., 2009). During the early Eocene this location was warm and strongly influenced by freshwater input and high nutrient concentrations (Sluijs et al., 2009).

\section{2. $\delta^{13} \mathrm{C}$ analyses of GDGT-derived biphytanes}

All sediment samples were extracted by means of a Dionex Accelerated Solvent Extractor (ASE) using a 9:1 (v:v) mixture of dichloromethane (DCM) and methanol $(\mathrm{MeOH})$, at high pressure $\left(7.6 \times 10^{6} \mathrm{~Pa}\right)$ and temperature $\left(100^{\circ} \mathrm{C}\right)$. An aliquot of the total extract was separated into an apolar and a polar fraction using a small column with activated alumina $\left(\mathrm{Al}_{2} \mathrm{O}_{3}\right)$ using $n$-hexane/DCM $(9: 1, v / v)$ and $\mathrm{MeOH} / \mathrm{DCM}(1: 1, \mathrm{v} / \mathrm{v})$ as eluents, respectively. The GDGTs, present in the polar fraction, were analyzed by high pressure liquid chromatography-mass spectrometry (HPLC-MS) as previously described by Sluijs et al. (2009) for Arctic Ocean ETM2, and Schoon (2013) for the North Sea Basin PETM, to determine their relative abundances.

To be able to analyze the stable carbon isotopic composition of these lipids, the polar fractions were refluxed with $56 \mathrm{wt} \% \mathrm{HI}$ (in $\mathrm{H}_{2} \mathrm{O}$ ) for $1 \mathrm{~h}$, which cleaves the ether bonds of GDGTs and releases their isoprenoid carbon skeletons (Schouten et al., 1998). The biphytanes were analyzed by gas chromatography (GC), gas chromatography/mass spectrometry (GC/MS) and isotope ratio monitoring-GC/MS as described in Schoon et al. (2011). All carbon isotopic values were determined at least in duplicate and are averaged to obtain a mean and a standard deviation $(\sigma)$, which are reported in the $\delta^{13} \mathrm{C}$ notation relative to the VPDB standard.

\section{Results}

\subsection{Variation in GDGT distribution}

HPLC-MS analysis of the North Sea Basin PETM sediments showed that crenarchaeol is the most dominant GDGT throughout the entire Fur section (Figs. 2A and 3). Before and after the CIE, crenarchaeol is only slightly higher in relative abundance than GDGT-0, but during the entire PETM interval the abundance of crenarchaeol increases up to $75 \%$ of total GDGTs (Fig. 3). The relative abundance of GDGTs in sediments deposited in the Arctic Basin do not show substantial variations across ETM2, with crenarchaeol being generally more abundant than GDGT-0 (Fig. 4). In both the PETM and ETM2 sediments, GDGT-1, -2 , and -3 are only minor components (combined ranging from $0 \%$ to $20 \%$ of all GDGTs) (Figs. 3 and 4). TEX ${ }_{86}$ temperatures derived from these GDGTs at the North Sea Basin PETM sections vary from ca. $17-24{ }^{\circ} \mathrm{C}$ prior to the CIE to up to $30^{\circ} \mathrm{C}$ during the CIE (Schoon, 2013). For the Arctic ETM2 section, $\mathrm{TEX}_{86}^{\prime}$ temperatures were $21-23^{\circ} \mathrm{C}$ prior to the CIE and rose to up to $26-27{ }^{\circ} \mathrm{C}$ during the CIE (Sluijs et al., 2009). Values of the BIT index, a proxy for the input of soil-derived GDGTs (Hopmans et al., 2004), are generally $<0.1$ prior to, and 
A

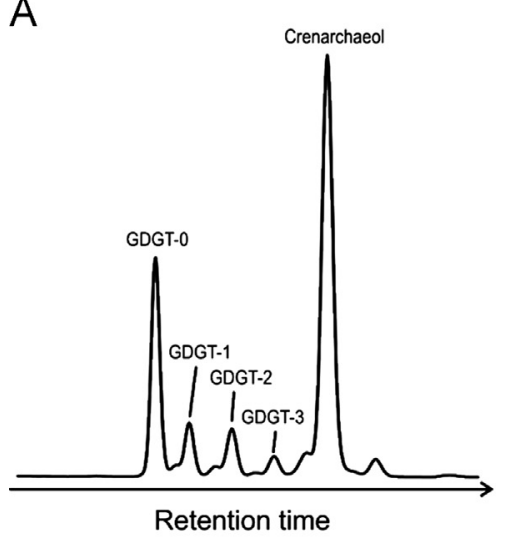

C
B

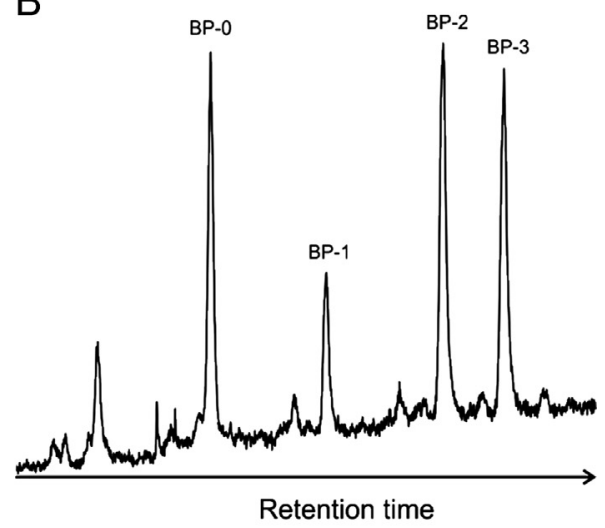

\begin{tabular}{ccc}
\hline GDGT structure & $\mathbf{x}$ & $\mathbf{y}$ \\
\hline GDGT-0 & BP-0 & BP-0 \\
GDGT-1 & BP-0 & BP-1 \\
GDGT-2 & BP-1 & BP-1 \\
GDGT-3 & BP-1 & BP-2 \\
GDGT-4* & BP-2 & BP-2 \\
Crenarchaeol & BP-2 & BP-3 \\
\hline "not analysed in this study &
\end{tabular}

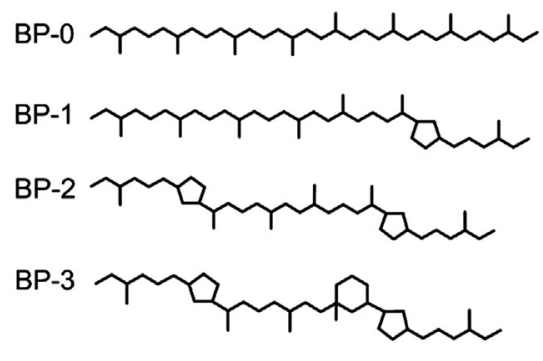

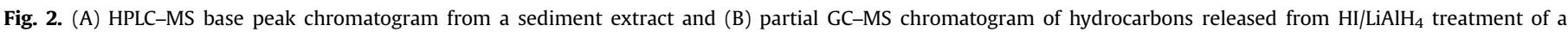
sediment extract from the CIE of the PETM (130.89 $\mathrm{m}$ at Store Bælt; Table 1), (C) Structures of the GDGTs and associated biphytanes.

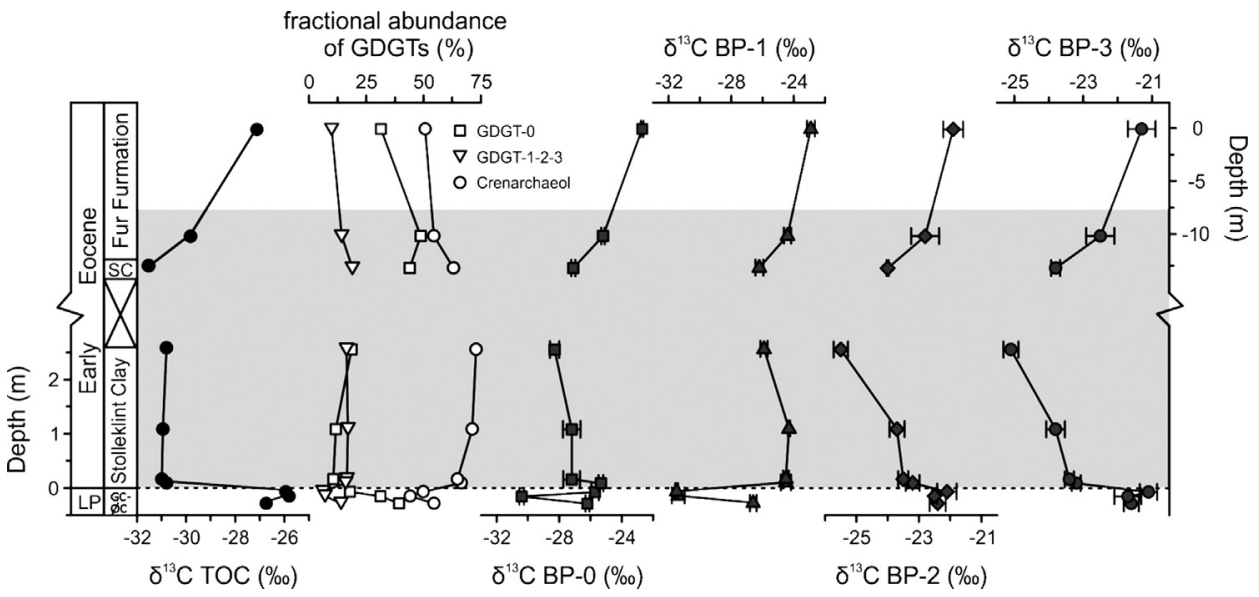

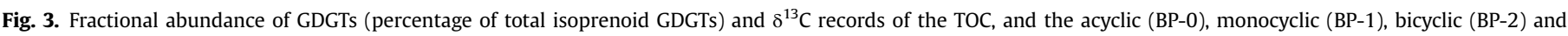

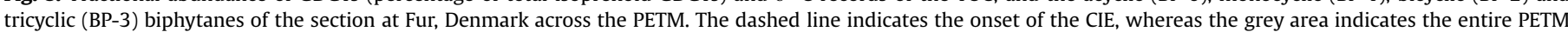
interval. Abbreviations: $\mathrm{LP}=$ Late Paleocene, $\mathrm{GS}-\varnothing \mathrm{C}=$ Glauconitic Silt-Østerrende Clay, $\mathrm{SC}=$ Stolleklint Clay.

during, the CIE in the Arctic Basin sediments (Sluijs et al., 2009) as well as during the CIE in the North Sea basin PETM sediments (Schoon, 2013), signifying low soil input (Schouten et al., 2013 and references cited therein). Only prior to the PETM, North Sea Basin sediments have elevated BIT values ranging from 0.3 to 0.7 (Schoon, 2013).

Upon chemical degradation of the GDGTs with $\mathrm{HI} / \mathrm{LiAlH}_{4}$, four biphytanes, i.e., an acyclic (BP-0), a monocyclic (BP-1), a bicyclic (BP-2) and a tricyclic (BP-3) biphytane (e.g. Fig. 2A and B), were generated. The latter structure contains, besides two cyclopentane moieties, also a cyclohexane moiety and has been shown to exclusively derive from crenarchaeol (Schouten et al., 2000; Sinninghe Damsté et al., 2002). Theoretically, the abundance of the released biphytanes depends on the relative concentration of the GDGTs and on the type of GDGT. For instance, both GDGT-0 and GDGT- 1 contribute to the total pool of BP-0. However, GDGT-1 is only a minor contributor to the total pool of GDGTs and contains only one BP-0 moiety. This is in contrast to GDGT-0, which is a dominant GDGT in all samples and contains two BP-0 moieties (Fig. 2C). Therefore, GDGT-0 contributes substantially more to the 


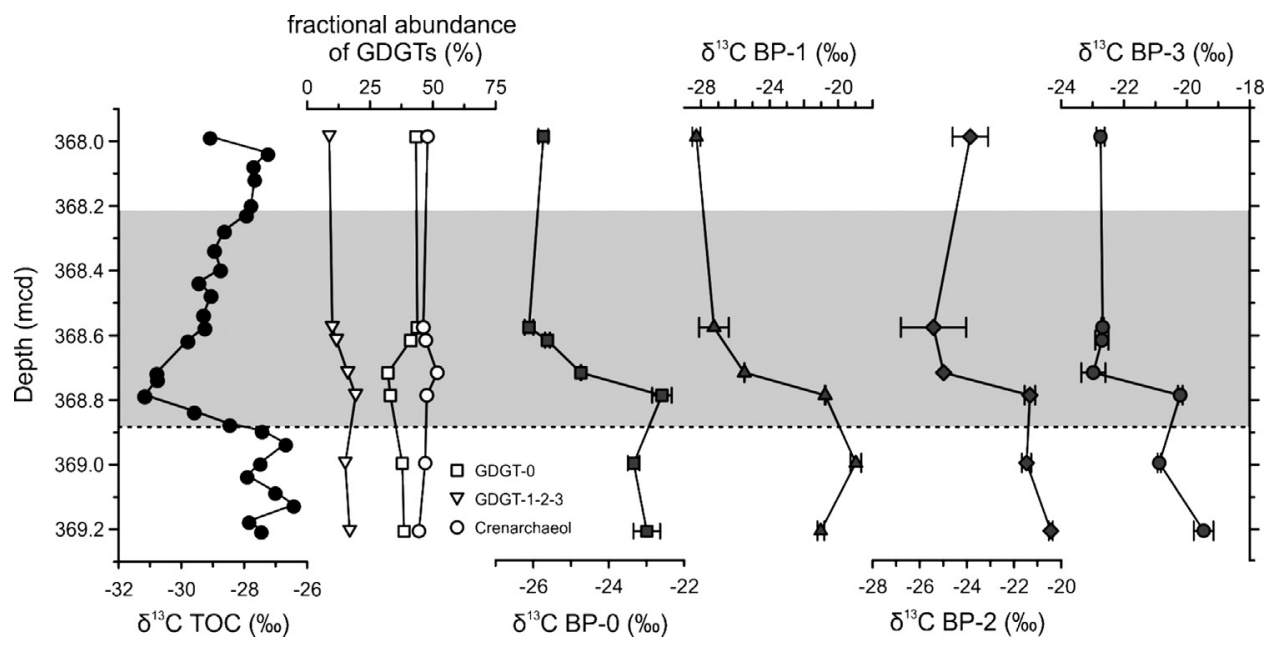

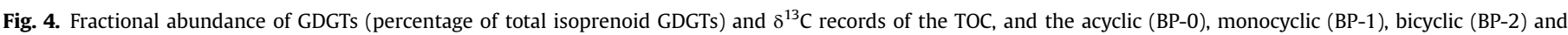

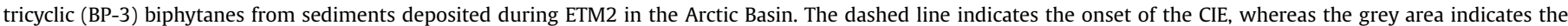
entire ETM2 interval.

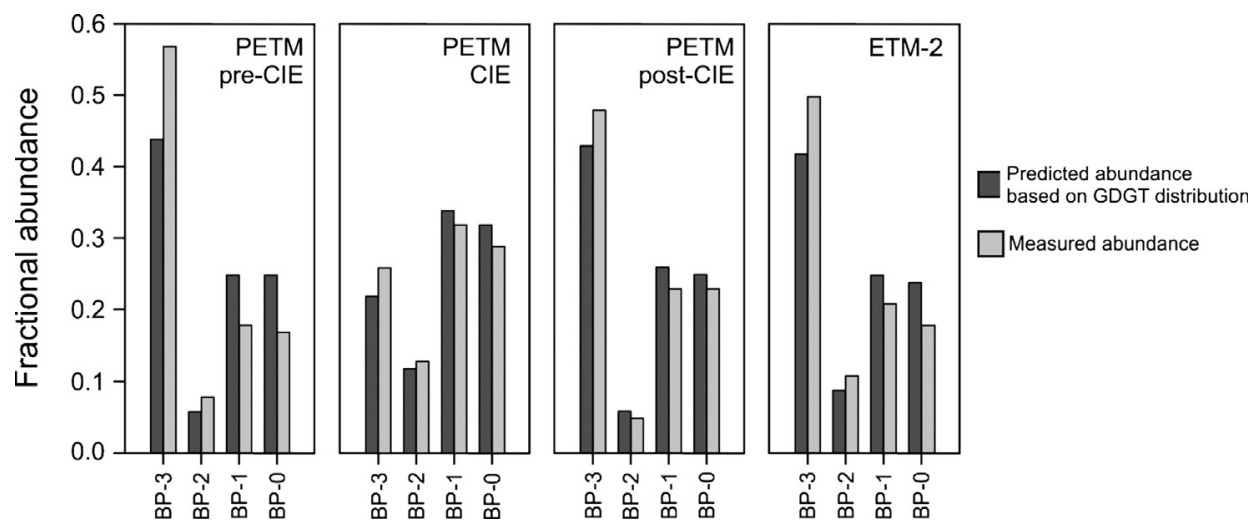

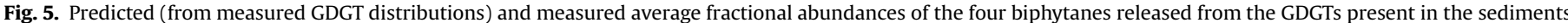
representing intervals of the pre-CIE, CIE, post-CIE PETM and in the interval representing the entire ETM2.

total BP-0 pool than GDGT-1. Thus, if we assume that GDGT-4 does not contribute to the total pool of GDGTs in the PETM and ETM2 sediments and that GDGT-2 consists of two BP-1 moieties, it is possible to predict the distribution of the biphytanes from the distribution of the GDGTs. The relative amount of the biphytanes can then be calculated using the following formulas:

$f_{\mathrm{BP}-0}=f_{\mathrm{GDGT}-0}+1 / 2 \times f_{\mathrm{GDGT}-1}$

$f_{\mathrm{BP}-1}=1 / 2 \times f_{\mathrm{GDGT}-1}+f_{\mathrm{GDGT}-2}+1 / 2 \times f_{\mathrm{GDGT}-3}$

$f_{\mathrm{BP}-2}=1 / 2 \times f_{\text {cren }}+1 / 2 \times f_{\mathrm{GDGT}-3}$

$f_{\mathrm{BP}-3}=1 / 2 \times f_{\text {cren }}$

in which $f$ stands for the fraction of the component. This calculated distribution fits generally well with the actual biphytane distribution observed after $\mathrm{HI}_{-} \mathrm{LiAlH}_{4}$ degradation (Fig. 2A, B and Fig. 5). At the onset of the CIE of the PETM, the ratio of BP-2 and BP- 3 with respect to BP-0 increased substantially, in agreement with the dominance of crenarchaeol in these sediments (Fig. 5). After the PETM, the biphytane abundance equals those from prior to the PETM (Fig. 5). We further observe no substantial variation in biphytane distribution in the sediments from the Arctic Basin from before, during or after ETM2 (Fig. 5). That is, BP-0 is the most abundant, followed by BP-2 and BP-3. In all samples BP-1 is lowest in abundance (Fig. 5).

\subsection{Stable carbon isotopic compositions of acyclic and cyclic biphytanes}

Despite the fact that GDGTs were detected in all sediments by HPLC-MS, it was not always possible to obtain $\delta^{13} \mathrm{C}$ values of the biphytanes. For example, in most Late Paleocene sediments, with TOC contents $<1 \%$, biphytanes were below detection limit or only present in trace amounts. This corresponds well with the fact that absolute GDGT concentrations in these sediments are low ( $<0.1 \mu \mathrm{g} \mathrm{g}^{-1}$; Schoon et al., 2012). Therefore, we could only obtain relatively complete (i.e. covering the CIE) biphytane $\delta^{13} \mathrm{C}$ records for the PETM of the Fur section and ETM2 of the Arctic Basin, whereas for the other two Danish PETM sections we only obtained $\mathrm{CIE}$ and post-CIE $\delta^{13} \mathrm{C}$ values.

\subsubsection{PETM-North Sea}

In general, BP-3 is most enriched in ${ }^{13} \mathrm{C}$, with $\delta{ }^{13} \mathrm{C}$ values varying from $-20 \%$ o to $-25 \%$, whereas BP-0 is generally the most ${ }^{13} \mathrm{C}$-depleted from $-22 \%$ down to values of $-31 \%$ (Table 1 ). Intermediate $\delta^{13} \mathrm{C}$ values are recorded for the other biphytanes. At the Fur section, BP-2 and BP-3 have $\delta^{13} \mathrm{C}$ values of around $-22 \%$ and $-21 \%$, respectively, prior to the CIE of the PETM (Fig. 3). Both biphytanes show an initial shift of $1.5-2.0 \%$ coincident with the onset of the CIE in OC (Fig. 3) and peak $\delta^{13} \mathrm{C}$ values are reached just before the glacially-disturbed interval with a maximum negative 
shift of 3.2\% in BP-2 and 3.6\% in BP-3, respectively. Subsequently, the $\delta^{13} \mathrm{C}$ values of these biphytanes increase, towards values slightly more negative than pre-excursion values. We observe a different $\delta^{13} \mathrm{C}$ pattern for BP-0 and BP-1. Prior to the CIE in OC both biphytanes show a distinct negative shift to depleted values of $\sim-31 \%$ after which they return to initial $\delta^{13} \mathrm{C}$ values of around $-25 \%$ at and just after the onset of the CIE. Subsequently, both BP-0 and BP-1 $\delta{ }^{13} \mathrm{C}$ values show a gradual negative shift towards peak values of around $-28 \%$ and $-26 \%$, respectively. The $\delta^{13} \mathrm{C}$ biphytane values of the CIE and post-CIE sections at Store Bælt and Ølst-Hinge, compare well with those in the equivalent sections at Fur (Table 1).

\subsubsection{ETM2-Arctic ocean}

Biphytane values range from $-19 \%$ to $-28 \%$ for the Arctic Basin sediments (Table 1). As for the PETM in the North Sea, BP-3 is the most enriched in ${ }^{13} \mathrm{C}$, whereas $\mathrm{BP}-0$ is in general the most ${ }^{13} \mathrm{C}$-depleted. Prior to the CIE of ETM2, BP-2 and BP-3 have similar $\delta^{13} \mathrm{C}$ values of around $-21 \%$ and $-20 \%$, respectively. All biphytanes shift towards more negative $\delta^{13} \mathrm{C}$ values during the $\mathrm{CIE}$, though these shifts occur slightly after the CIE in OC, i.e. at $368.79 \mathrm{mcd}$ versus $368.72 \mathrm{mcd}$, respectively (Fig. 4). The negative shift recorded in BP-3 is $\sim 2.5 \%$ (Fig. 4 ), whereas the negative shift in BP-2 is larger, $\sim 4.2 \%$. For BP-0 a similar shift is observed at $\sim 3 \%$ o but much larger shift is found for BP-1, $\sim 6 \%$ (Fig. 4 and Table 1 ).

\section{Discussion}

\subsection{Sources of the ether-bound biphytanes}

The tricyclic biphytane (BP-3), which consists of two cyclopentyl moieties and one cyclohexyl moiety (Fig. 2C), derives exclusively from crenarchaeol, a specific membrane lipid of Thaumarchaeota (Pitcher et al., 2011 and references cited therein). The bicyclic biphytane (BP-2) is also part of the carbon skeleton within crenarchaeol but can also be sourced from other GDGTs, such as GDGT-3 or GDGT-4 (Fig. 2C). This latter GDGT was not analyzed in this study. It is likely that BP-0 predominantly derives from GDGT-0, while BP-1 is mainly sourced from GDGTs- 1 and -2 , which only have minor contributions to the GDGT-pool in the PETM and ETM2 sediments (Figs. 3 and 4).

Könneke et al. (2012) showed in their culture study of $N$. maritimus that biphytanes derived from a single GDGT have identical $\delta{ }^{13} \mathrm{C}$ values. Therefore, to examine whether the individual biphytanes in the PETM and ETM2 sediments are all derived from Thaumarchaeota, we compared the $\delta^{13} \mathrm{C}$ compositions of $\mathrm{BP}-0$, predominantly derived from GDGT-0, BP-1 and BP-2, which can originate from multiple GDGTs, with that of BP-3, which derives solely from thaumarchaeotal-derived crenarchaeol (Fig. 6A). The most significant relationship observed is that between BP-3 and $\mathrm{BP}-2$, which generally have similar $\delta^{13} \mathrm{C}$ values and lie close to the $1: 1$ line. This strongly suggests that BP-2 is also predominantly derived from crenarchaeol (cf. Schouten et al., 1998). The correlation between the $\delta^{13} \mathrm{C}$ values of BP-3 and the other two biphytanes (BP-0 and BP-1) is considerably less and frequently they have substantially different $\delta^{13} \mathrm{C}$ values. The $\delta^{13} \mathrm{C}$ values of both BP-0 and $\mathrm{BP}-1$ are nearly always depleted in ${ }^{13} \mathrm{C}$ compared to the $\delta^{13} \mathrm{C}$ values of BP-3, i.e. on average by $3 \%$ for $\mathrm{BP}-0$ and $1.5 \%$ or $\mathrm{BP}-1$ (Fig. 6A). These ${ }^{13} \mathrm{C}$-depleted values relative to those of $\mathrm{BP}-2$ and $\mathrm{BP}-3$ suggest they may have additional sources other than Thaumarchaeota, such as methanotrophs and methanogens, which are known to synthesize lipids with more depleted $\delta^{13} \mathrm{C}$ values (e.g., Summons et al., 1998). Schouten et al. (1998) showed that in marine sediments the isotopic difference between BP-3 and BP-0 is larger with higher concentrations of BP-0 (i.e., GDGT-0)
A

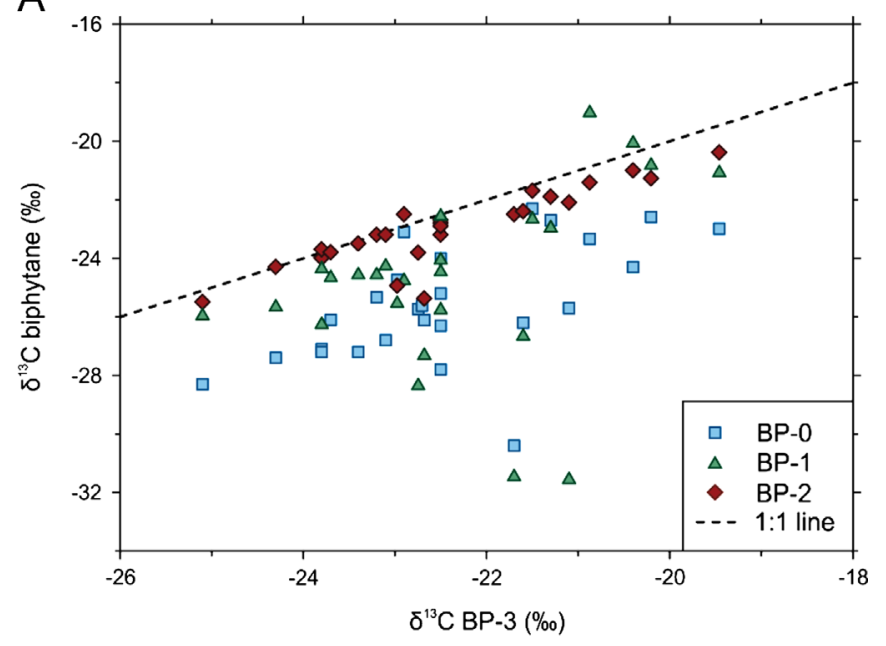

B

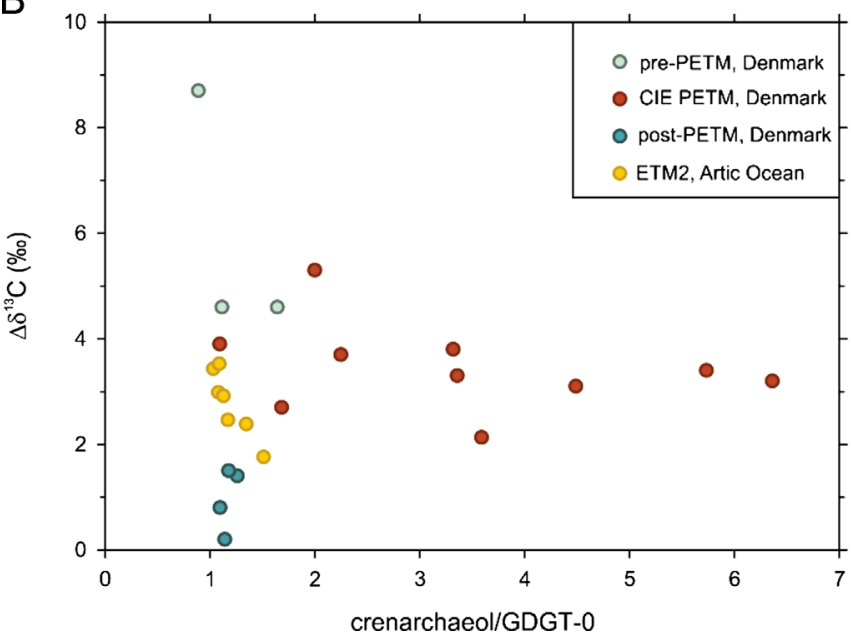

Fig. 6. (A) Cross-correlations of the stable carbon isotope composition of BP-3 with those of BP-0, BP-1 and BP-2. The dotted line indicates the 1:1 line. (B) Difference in stable carbon isotope composition $\left(\Delta \delta^{13} \mathrm{C}\right)$ of BP-3 and BP-0 as a function of the ratio of crenarchaeol and GDGT-0.

compared to that of BP-3 (i.e., crenarchaeol). They attributed this trend to an additional ${ }^{13} \mathrm{C}$-depleted source of GDGT-0, likely through a contribution of methanogens. However, we do not observe such a trend in our data (Fig. 6B). Instead, we find a relatively consistent isotopic offset of $3 \pm 0.9 \%$ between $\mathrm{BP}-0$ and BP-3 for the CIE of the PETM and ETM2, independent of the relative amount of crenarchaeol. Nevertheless, the difference in isotopic compositions does suggest sources in addition to Thaumarchaeota for GDGT-0. This is, however, not the case for the postPETM samples from the North Sea, which exhibit no significant isotopic difference.

An input of GDGTs from sources other than Thaumarchaeota could potentially bias $\mathrm{TEX}_{86}$ records as this index includes GDGTs-1 and -2 and assumes they are solely derived from Thaumarchaeota. Indeed, the relatively negative $\delta^{13} \mathrm{C}$ values of BP-1 before the onset of the PETM in sediments from the Danish section at Store Bælt coincide with relatively cool temperatures and a large variability in $\mathrm{TEX}_{86}$ temperatures from $17-24^{\circ} \mathrm{C}$ (Schoon, 2013). This coincides with relatively high BIT values ( $>0.3$ ) suggesting that GDGT-1 carries a large imprint of soil-derived GDGTs which potentially could be depleted in ${ }^{13} \mathrm{C}$ relative to their marine counterparts. Since GDGT-1 is in lowest abundance, the imprint of soil derived GDGTs could be most noticeable with this isomer, in contrast to the other biphytanes that are derived from more abundant GDGTs such as 
GDGT-0 and crenarchaeol. The input of soil derived GDGTs could thus potentially have biased the sedimentary GDGT distribution, in particular GDGT-1 and -2, and lead to lower and variable TEX 86 values. However, Schoon (2013) also found that independently reconstructed continental air temperatures using the distribution of branched GDGTs, derived from soil bacteria, show similar trends as the $\mathrm{TEX}_{86}$ record, suggesting that input of non-Thaumarchaeotal sourced GDGTs may have not affected $\mathrm{TEX}_{86}$ records to a large degree.

In any case, the similar isotopic composition, and changes therein, between BP-3 and BP-2 (Fig. 6B) supports the idea that both biphytanes derive from crenarchaeol and therefore their $\delta^{13} \mathrm{C}$ values reflect that of crenarchaeol.

\subsection{Magnitude and timing of the CIE in Thaumarchaeota}

The magnitude of the carbon isotope excursion for BP-2 and BP-3 at the Danish PETM section at Fur, where we have a complete isotope record, is $3.6 \pm 0.3 \%$ (Fig. 3). This is considerably less than measured in OC (5-6\%) and $n$-alkanes (6-7\%) at this location (Schoon et al., 2012), but is similar to the $\sim 3 \%$ CIE measured in marine calcite elsewhere (McInerney and Wing, 2011; Dickens, 2011) and isotope records of marine organic matter (Sluijs and Dickens, 2012). Possibly, peak values are masked by the glaciallydisturbed interval at Fur (Schoon et al., 2012) and, therefore, the $\mathrm{CIE}$ in crenarchaeol may be underestimated. However, the $\delta^{13} \mathrm{C}$ values of BP-3 at the CIE sections of Store Bælt and Ølst-Hinge are nearly identical to that of Fur (Table 1), suggesting that the minimum values in the crenarchaeol record at Fur correspond to the minimum values in the exogenic carbon pool, and thus the CIE in crenarchaeol is unlikely to be higher than 3.6\%o.

The magnitude of the CIE recorded in BP-3 at ETM2 is $\sim 2.5 \pm 0.7 \%$. This is slightly lower than that measured for TOC (3.1\%o; Table 1), but similar when the OC record is corrected for terrestrial organic matter contributions (2.5\%o; Sluijs and Dickens, 2012). It is smaller than excursions found for marine biomarkers, which ranged from $3.2 \%$ to $4.5 \%$ (Schoon et al., 2011), but larger than the $1.4 \%$ excursion of benthic foraminifera as measured at Walvis Ridge (Stap et al., 2010). The larger magnitude of the CIE in the marine algal biomarkers may be due to enhanced $\mathrm{CO}_{2}$ concentrations leading to increased isotopic fractionations (e.g. Schoon et al., 2011; Sluijs and Dickens, 2012). The difference between the CIE in crenarchaeol versus that in marine calcite potentially reflect mixing effects, local variations in the magnitude of the different CIEs in the DIC (specifically bicarbonate) of the semi-restricted Arctic Basin and South Atlantic Ocean, or it may reflect an impact of environmental factors on the isotopic fractionation of marine Thaumarchaeota.

Intriguingly, the timing of the CIE of crenarchaeol apparently differs to that recorded in OC and marine biomarkers for ETM2. Where the marine biomarker and marine organic matter CIEs all track the negative shift in $\delta^{13} C_{\mathrm{TOC}}$ at 368.90 mcd marking the onset of ETM2 (Sluijs et al., 2009; Schoon et al., 2011; Sluijs and Dickens, 2012), the $\delta^{13} \mathrm{C}$ negative shift in BP-3 occurs later, i.e. between 368.79 and 368.72 mcd (Fig. 4). It is unclear why the sediment at 368.79 mcd does not show a more negative $\delta^{13} \mathrm{C}$ compared to pre$\mathrm{CIE}$ values. Although it is a single point in the record (attempts to obtain isotope data for other depth intervals were not successful), the other marine biomarkers in the same sediment interval already show a negative shift of $\sim 1-2 \%$ (Schoon et al., 2012). One possibility to explain the apparent delayed onset of the CIE of crenarchaeol, as well as the relatively large CIE compared to deep marine calcite, is that euxinic conditions developed in the deeper part of the photic zone during ETM2, as evidenced by the presence of derivatives of the biomarker isorenieratene derived from anoxygenic phototrophic green sulfur bacteria (Sluijs et al.,
2009). In the contemporary euxinic Black Sea, Thaumarchaeota reside at the deeper and colder chemocline (Coolen et al., 2007), where $\delta^{13} C_{\text {DIC }}$ values are always substantially more negative than at the surface (e.g., - $4.5 \%$ for the Black Sea chemocline; Freeman and Wakeham, 1991) due to the production of depleted $\mathrm{CO}_{2}$ by mineralization of descending particles rich in ${ }^{13} \mathrm{C}$-depleted organic matter (Fry et al., 1991; Freeman and Wakeham, 1991). It is therefore possible that the $\delta^{13} \mathrm{C}$ of crenarchaeol may be more negative due to the migration of the Thaumarchaeota to deeper waters. Indeed, the $\delta^{13} \mathrm{C}$ negative shift of the biphytanes at ETM2 coincides with peak concentrations of derivatives of the specific biomarker isorenieratene and with a sharp cooling of temperatures inferred from TEX' $_{86}$ (Sluijs et al., 2009). Furthermore, BP-1 shows an even larger depletion in ${ }^{13} \mathrm{C}$ at this time by up to $6 \%$, suggesting that it is derived from deeper-dwelling archaea (Table 1). This may imply that the Thaumarchaeota responded to the arising euxinic conditions at this location by migrating down towards the chemocline, thereby yielding lower $\mathrm{TEX}_{86}$ temperatures (cf. Menzel et al., 2006) and depleted ${ }^{13} \mathrm{C}$-values. At 368.79 mcd, where a CIE of crenarchaeol is not yet exhibited, no isorenieratane was detected (Schoon et al., 2012) and thus euxinic conditions, which likely already developed in the bottom waters, did not reach the photic zone at this depth interval. Possibly, the Thaumarchaeota migrated initially upwards during the first stages of the CIE such that the CIE was partly offset by the more enriched $\delta^{13} C_{\text {DIC }}$ in the surface waters compared to deeper waters. This is supported by the recorded increase in temperatures as derived from $\mathrm{TEX}_{86}$.

The apparent correlation between development of photic zone euxinia and increasing ${ }^{13} \mathrm{C}$-depletion in crenarchaeol during ETM2, does not seem to apply for the eastern North Sea Basin during the PETM. Schoon (2013) also found isorenieratene derivatives in the sediments at the Fur section, suggesting that photic zone euxinia existed throughout the CIE. However, the $\mathrm{TEX}_{86}$ temperature records from all three Danish sites do not show any cooling events during the CIE of the PETM but rather a warming trend, as observed globally in PETM sections (Schoon et al., 2012). This suggests that the niche of the Thaumarchaeota remained relatively constant there and possibly at shallower depths than in the Arctic Basin, with no apparent migration to deeper waters.

It remains also possible that the $2.5 \% \mathrm{CIE}$ as recorded for ETM2 in the Arctic is simply larger than the CIE of the global exogenic carbon pool. Similar to the PETM, the CIE of crenarchaeol at ETM2 in the Arctic Basin is smaller than that recorded in other biomarkers such as sulfur-bound phytane and $\mathrm{C}_{25} \mathrm{HBI}$, which showed CIEs of $3.2 \%$ and $4.5 \%$, respectively (Schoon et al., 2011). Schoon et al. (2011) attributed the large magnitude of the CIE in these algal biomarkers to enhanced $\mathrm{CO}_{2}$ concentrations. In contrast, the $\delta^{13} \mathrm{C}$ compositions of Thaumarchaeal lipids are independent to variations in DIC concentration, at least in culture experiments, and may predominantly depend on $\delta^{13} \mathrm{C}$ of DIC only (Könneke et al., 2012). Therefore, it may well be that the $\delta^{13} C_{D I C}$ in the Arctic basin decreased relative to the global exogenic carbon pool, as previously hypothesized (Sluijs and Dickens, 2012) based on a recorded regional increase in fresh-water input (Sluijs et al. 2009).

The $\delta^{13} \mathrm{C}$ values of BP-3 do not only allow to reconstruct variations in $\delta^{13} C_{\text {DIC }}$ but possibly also absolute $\delta^{13} C_{\text {DIC }}$ values of the upper part of the water column, assuming the constant fractionation between biphytanes and DIC of ca. $20 \%$ observed in cultures (Könneke et al., 2012) and present-day marine settings (Schouten et al., 2013). Pre-PETM $\delta^{13} \mathrm{C}_{\text {DIC }}$ estimates range between $-1 \%$ and $-2 \%$, more negative than contemporary $\delta^{13} C_{\text {DIC }}$ values observed in North Sea surface waters ( $1 \%$; Mook and Tan, 1991). Pre-ETM2 $\delta^{13} \mathrm{C}_{\mathrm{DIC}}$ estimates are $\sim 0 \%$, also lower than those observed in present-day Greenland Sea $(\sim 1.5 \%$; Kroopnick et al., 1985 ) and the estimated surface water $\delta^{13} C_{\text {DIC }}$ value of $\sim 1 \%$ in the 
Nansen Basin in the Arctic Ocean inferred from planktonic foraminifera (Bauch et al., 2000). This is in contrast with planktonic and benthic foraminifera records, which suggests that late Paleocene $\delta^{13} C_{\text {DIC }}$ is likely to have been slightly more enriched in ${ }^{13} \mathrm{C}$ compared to present day (Hayes et al., 1999; Zachos et al., 2001). One explanation could be that while at present both the North Sea and the Arctic Ocean are relatively open systems with inflow of well oxygenated waters, in the Early Palaeogene they were likely semi-enclosed basins with restricted inflow from the Atlantic or Tethys Ocean (Moran et al., 2006; Brinkhuis et al., 2006; Stein et al., 2006; Kender et al., 2012). This is comparable to estuarine circulation conditions of the Black Sea, where, due to intense recycling of $\mathrm{CO}_{2}$, surface water $\delta^{13} \mathrm{C}_{\mathrm{DIC}}$ values in the Black Sea are in general lower than those of open waters (e.g., Fry et al., 1991). Thus, local $\delta^{13} C_{\text {DIC }}$ values in the North Sea and Arctic Basins may have been more negative, due to restricted circulation, compared to the open ocean.

Alternatively, and perhaps more likely, the $\delta^{13} \mathrm{C}$ of crenarchaeol is not reflecting the $\delta^{13} C_{\text {DIC }}$ of surfaces waters but that of the upper part of the water column where there is a gradient in $\delta^{13} C_{D I C}$, i.e. an increasing depletion in ${ }^{13} \mathrm{C}$ with depth. Several studies have shown that GDGTs in surface sediments may not only derive from surface waters but also from deeper water layers (e.g. Pearson et al., 2001a; Huguet et al., 2007; Shah et al., 2008; Lopes dos Santos et al., 2010). In fact, TEX $_{86}$ values in surface marine sediments have been shown to correlate well with the average 0-200 $\mathrm{m}$ water temperatures (Kim et al., 2012). Thus, the $\delta^{13} \mathrm{C}$ value of crenarchaeol may well be a depth-integrated signal of the upper part of the water column rather than merely of surface waters. Furthermore, as discussed above, development of a strong chemocline may also alter the depth habitat of Thaumarchaeota, and thus the isotopic signal carried by crenarchaeol. These factors may explain some potential differences in magnitude and timing of the CIE in the $\delta^{13} \mathrm{C}$ value of crenarchaeol versus that of the calcite of planktonic foraminifera.

Nevertheless, our results suggest that the $\delta^{13} \mathrm{C}$ values of Thaumarchaeotal biphytanes have the potential to record variations in $\delta^{13} C_{D I C}$ and can give insight in the magnitude of the carbon isotope excursions of the exogenic carbon pool during hyperthermals. The similar CIE of crenarchaeol compared to that of marine calcite during the PETM suggests that the marine DIC pool shifted with a maximum of $3.6 \%$, which is consistent with that found by Sluijs and Dickens (2012) in marine organic matter from the Lomonosov Ridge after correcting the TOC record for terrestrial contributions. However, CIEs in $\delta^{13} C_{\text {DIC }}$ were unlikely uniform across semi-enclosed basins, coastal seas and open oceans because of regional deviations from the global exogenic carbon pool (e.g., Sluijs and Dickens, 2012). Therefore, to precisely constrain the magnitude of the CIEs in global ocean DIC based on $\delta^{13} \mathrm{C}$ values of crenarchaeol, data from other PETM sites are required. Furthermore, potential factors influencing the magnitude of isotopic fractionation by Thaumarchaeota, such as temperature, growth rate and mixotrophy, should also be tested using culture experiments, although the relative consistent $\delta^{13} \mathrm{C}$ values of crenarchaeol in modern settings (Hoefs et al., 1997; Schouten et al., 2013 and references cited therein) suggest these factors may be of relative minor importance.

\section{Conclusions}

We examined the potential use of stable carbon isotopes of Thaumarchaeotal GDGTs as a proxy for $\delta^{13} C_{\text {DIC }}$ in order to reconstruct the CIE of marine dissolved inorganic carbon during Eocene hyperthermals. The similar $\delta^{13} \mathrm{C}$ composition of the tricyclic and bicyclic biphytanes in PETM and ETM2 sediments suggest they are both derived from the Thaumarchaeotal biomarker crenarchaeol, while other GDGTs have a more ${ }^{13} \mathrm{C}$-depleted signature, suggesting additional sources. The reported, relatively constant carbon isotopic fractionation $(\sim 20 \%$ o) between the biphytanes and DIC, allowed us to reconstruct $\delta^{13} \mathrm{C}_{\text {DIC }}$ records across two Eocene hyperthermals. We record $\delta^{13} \mathrm{C}_{\text {DIC }}$ shifts of $\sim 3.6 \%$ (from $0.5-1 \%$ o to $\sim 4.6 \%$ ) and $\sim 2.5 \%$ (from $\sim 0.5 \%$ o to $\sim 3 \%$ ) in the $\delta^{13} \mathrm{C}$ of crenarchaeol for PETM and ETM2, respectively, which are similar and slightly higher, respectively, than that of marine calcite. This suggests that the negative carbon isotope shifts recorded in crenarchaeol may record changes in marine DIC at these sites during these Eocene hyperthermals.

\section{Acknowledgments}

We thank the editor Dr. E. Henderson, Dr. R. Pancost and an anonymous reviewer for their constructive comments which improved the manuscript. We thank C. Heeren, M. Kienhuis, J. Ossebaar, A. Mets and M. Baas for their laboratory and technical support. The Darwin Center for Biogeosciences partially funded this project. Financial support also came from a Vici grant from the Netherlands Organisation for Scientific Research to SS. AS thanks the European Research Council under the European Community's Seventh Framework Program for ERC Starting Grant no. 259627.

\section{References}

Backman, J., Moran, K., McInroy, D.B., Mayer, L.A., and Expedition-302-Scientists, 2006. Proceedings of the Integrated Ocean Drilling Program 302, Integrated Ocean Drilling Program Management International, Inc., Edinburgh.

Bauch, D., Carstens, J., Wefer, G., Thiede, J., 2000. The imprint of anthropogenic $\mathrm{CO}_{2}$ in the Arctic Ocean: evidence from planktic $\delta^{13} \mathrm{C}$ data from watercolumn and sediment surface. Deep-Sea Res. II 47, 1791-1808.

Berg, I.A., Kockelkorn, D., Buckel, W., Fuchs, G., 2007. A 3-hydroxypropionate/4hydroxybutyrate autotrophic carbon dioxide assimilation pathway in archaea. Science 318, 1782-1786.

Brinkhuis, H., Schouten, S., Collinson, M.E., Sluijs, A., Sinninghe Damsté, J.S., Dickens, G.R., Huber, M., Cronin, T.M., Onodera, J., Takahashi, K., Bujak, J.P., Stein, R., Van Der Burgh, J., Eldrett, J.S., Harding, I.C., Lotter, A.F., Sangiorgi, F., Van Konijnenburg-Van Cittert, H., De Leeuw, J.W., Matthiessen, J., Backman, J., Moran, K., The Expedition 302 Scientists, 2006. Episodic fresh surface waters in the Eocene Arctic Ocean. Nature 441, 606-609.

Cramer, B.S., Wright, J.D., Kent, D.V., Aubry, M.-P., 2003. Orbital climate forcing of $\delta^{13} \mathrm{C}$ excursions in the late Paleocene-early Eocene (chrons C24n-C25n). Paleoceanography 18, 1097.

Coolen, M.J.L., Abbas, B., van Bleijswijk, J., Hopmans, E.C., Kuypers, M.M.M. Wakeham, S.G., Sinninghe Damsté, J.S., 2007. Putative ammonia-oxidizing Crenarchaeota in suboxic waters of the Black Sea: a basin-wide ecological study using $16 \mathrm{~S}$ ribosomal and functional genes and membrane lipids. Environ. Microbiol. 9, 1001-1016.

DeConto, R.M., Galeotti, S., Pagani, M., Tracy, D., Schaefer, K., Zhang, T., Pollard, D., Beerling, D.J., 2012. Past extreme warming events linked to massive carbon release from thawing permafrost. Nature 484, 87-92.

Dickens, G.R., O'Neil, J.R., Rea, D.K., Owen, R.M., 1995. Dissociation of oceanic methane hydrate as a cause of the carbon isotope excursion at the end of the Paleocene. Paleoceanography 10, 965-971.

Dickens, G.R., Castillo, M.M., Walker, J.C.G., 1997. A blast of gas in the latest Paleocene: simulating first-order effects of massive dissociation of oceanic methane hydrate. Geology 25, 259-262.

Dickens, G.R, 2011. Down the Rabbit Hole: toward appropriate discussion of methane release from gas hydrate systems during the Paleocene-Eocene thermal maximum and other past hyperthermal events. Clim. Past 7, 831-846.

Freeman, K.H., Wakeham, S.G., 1991. Variations in the distributions and isotopic compositions of alkenones in Black Sea particles and sediments. Org. Geochem. 19, 277-285

Fry, B., Jannasch, H.W., Molyneaux, S.J., Wirsen, C.O., Muramoto, J.A., King, S., 1991. Stable isotope studies of the carbon, nitrogen and sulfur cycles in the Black Sea and the Cariaco Trench. Deep-Sea Res. 38 (Suppl. 2), S1003-S1019.

Hallam, S.J., Mincer, T.J., Schleper, C., Preston, C.M., Roberts, K., Richardson, P.M., DeLong, E.F., 2006. Pathways of carbon assimilation and ammonia oxidation suggested by environmental genomic analyses of marine Crenarchaeota. PLoS Biol. 4, 520-536.

Hayes, J.M., Strauss, H., Kaufman, A.J., 1999. The abundance of ${ }^{13} \mathrm{C}$ in marine organic matter and isotopic fractionation in the global biogeochemical cycle of carbon during the past 800 Ma. Chem. Geol. 161, 103-125. 
Heilmann-Clausen, C., Schmitz, B., 2000. The late Paleocene thermal maximum $\delta^{13} \mathrm{C}$ excursion in Denmark? Geol. Forens. Forhand. 122, 70.

Hopmans, E.C., Weijers, J.W.H., Schefuß, E., Herfort, L., Sinninghe Damsté, J.S., Schouten, S., 2004. A novel proxy for terrestrial organic matter in sediments based on branched and isoprenoid tetraether lipids. Earth Planet Sci. Lett. 224, 107-116.

Hoefs, M.E.L., Schouten, S., King, L.L., Wakeham, S.G., De Leeuw, J.W., Sinninghe Damsté, J.S., 1997. Ether lipids of planktonic archaea in the marine water column. Appl. Environ. Microbiol. 63, 3090-3095.

Huguet, C., Schimmelmann, A., Thunell, R., Lourens, L.J., Sinninghe Damsté, J.S., Schouten, S., 2007. A study of the TEX ${ }_{86}$ paleothermometer in the water column and sediments of the Santa Barbara Basin, California. Paleoceanography http://dxdoi.org/10.1029/2006PA001310.

Jung, M-Y., Park, S-J., Min, D., Kim, J-S., Rijpstra, W.I.C., Sinninghe Damsté, J.S., Kim, G-J., Madsen, E.L., Rhee, S-K., 2011. Enrichment and characterization of an autotrophic ammonia-oxidizing archaeon of mesophilic crenarchaeal group I.1a from an agricultural soil. Appl. Environ. Microbiol. 77, 8635-8647.

Kender, S., Stephenson, M.H., Riding, J.B., Leng, M.J., Knox, R, O'B., W., Peck, V.L., Kendrick, C.P., Ellis, M.A., Vane, C.H., Jamieson, R., 2012. Marine and terrestrial environmental changes in NW Europe preceding carbon release at the Paleocene-Eocene transition. Earth. Planet. Sci. Lett. 353-354, 108-120.

Kim, J.H., Romero, O.E., Lohmann, L., Donner, B., Laepple, T., Haam, E., Sinninghe Damsté, J.S., 2012. Pronounced subsurface cooling of North Atlantic waters off Northwest Africa during Dansgaard-Oeschger interstadials. Earth Planet. Sci. Lett. 339-340, 95-102.

Könneke, M., Lipp, J.S., Hinrichs, K-U., 2012. Carbon isotope fractionation by the mairne ammonia-oxidizing archaeon Nitrosopumilis maritimus. Org. Geochem. $48,21-24$.

Könneke, M., de la Torre, J.R., Walker, C.B, Waterbury, J.B., Stahl, D.A., 2005. Isolation of an autotrophic ammonia-oxidizing marine archaeon. Nature 437, 543-546.

Kroopnick, P.M., 1985. The distribution of ${ }^{13} \mathrm{C}$ of $\Sigma \mathrm{CO}_{2}$ in the world oceans. DeepSea Res. 32, 54-84.

Kurtz, A.C., Kump, L.R., Arthur, M.A., Zachos, J.C., Paytan, A., 2003. Early Cenozoic decoupling of the global carbon and sulfur cycles. Paleoceanography 18, 14-114-13.

Kuypers, M.M.M., Blokker, P., Erbacher, J., Kinkel, H., Pancost, R.D., Schouten, S., Sinninghe Damsté, J.S., 2001. Massive expansion of marine archaea during a mid-Cretaceous oceanic anoxic event. Science 293, 92-94.

Laws, E.A., Popp, B.N., Bidigare, R., Kennicutt, M.C., Macko, S.A., 1995. Dependence of phytoplankton carbon isotopic composition on growth rate and [CO2]aq.: theoretical considerations and experimental results. Geochim. Cosmochim. Acta 59, 1131-1138.

Lengger, S.K., Hopmans, E.C., Reichart, G.-J., Sinninghe Damsté, J.S., Schouten, S., 2012. Intact polar and core glycerol dibiphytanyl glycerol tetraether lipids in the Arabian Sea Water Oxygen Minimum Zone: II. Selective preservation and degradation in sediments and consequences for the TEX $\mathrm{B}_{86}$. Geochim. Cosmochim. Acta, 98; 244-258.

Lopes dos Santos, R., Prange, M., Castañeda, I.S., Schefuß, E., Mulitza, S., Schulz, M., Niedermeyer, E.M., Sinninghe Damsté, J.S., Schouten, S., 2010. Glacial-interglacial variability in Atlantic meridional overturning circulation and thermocline adjustments in the tropical North Atlantic. Earth Planet. Sci. Lett. 300, $407-414$.

Lourens, L.J., Sluijs, A., Kroon, D., Zachos, J.C., Thomas, E., Röhl, U., Bowles, J., Raffi, I., 2005. Astronomical pacing of late Paleocene to early Eocene global warming events. Nature 435, 1083-1087.

McInerney, F.A., Wing, S.L., 2011. The Paleocene-Eocene Thermal Maximum-a perturbation of carbon cycle, climate, and biosphere with implications for the future. Annu. Rev. Earth Planet. Sci. 39, 489-516.

Menzel, D., Hopmans, E.C., Schouten, S., Sinninghe Damsté, J.S., 2006. Membrane tetraether lipids of planktonic Crenarchaeota in Pliocene sapropels of the eastern Mediterranean Sea. Palaeogeo. Palaeoclimatol. Palaeoecol. 239, 1-15.

Mook, W.G., Tan, F.C., 1991. Stable carbon isotopes in rivers and estuaries. In: Degens, E.T., et al. (Eds.), Biogeochemistry of Major World Rivers, 42. SCOPE, pp. 245-264.

Moran, K., Backman, J., Brinkhuis, H., Clemens, S.C., Cronin, T., Dickens, G.R., Eynaud, F., Gattacceca, J., Jakobsson, M., Jordan, R.W., Kaminski, M., King, J., Koc, N., Krylov, A., Martinez, N., Matthiessen, J., McInroy, D., Moore, T.C., Onodera, J., O'Regan, M., Palike, H., Rea, B., Rio, D., Sakamoto, T., Smith, D.C., Stein, R., St John, K., Suto, I., Suzuki, N., Takahashi, K., Watanabe, M., Yamamoto, M., Farrell, J., Frank, M., Kubik, P., Jokat, W., Kristoffersen, Y., 2006. The Cenozoic palaeoenvironment of the Arctic Ocean. Nature 441, 601-605.

Nicolo, M., Dickens, G.R., Hollis, C.J., Zachos, J.C., 2007. Multiple early Eocene hyperthermals: their sedimentary expression on the New Zealand continental margin and in the deep sea. Geology 35, 699-702.

Nielsen, O.B., Baumann, J., Zhang, D., Heilmann-Clausen, C., Larsen, G, 1986. Tertiary deposits in store bælt. In: Møller, J.T. (Ed.), Twenty five Years of Geology in Aarhus. Geoskrifter No. 24, Department of Geoscience, Aarhus University, pp. 235-253.

O'Regan, M., Moran, K., Backman, J., Jakobsson, M., Sangiorgi, F., Brinkhuis, H., Pockalny, R., Skelton, A., Stickley, C., Koc, N., Brumsack, H.J., Willard, D., 2008. Mid-Cenozoic tectonic and paleoenvironmental setting of the central Arctic Ocean. Paleoceanography 23, http://dx.doi.org/10.1029/2007PA001559, PA1S20.

Pagani, M., Caldeira, K., Archer, D., Zachos., J.C., 2006. An ancient carbon mystery. Science 314, 1556-1557.
Park, B.-J., Park, S.-J., Yoon, D.-N., Schouten, S., Sinninghe Damsté, J.S., Rhee, S.-K., 2010. Cultivation of autotrophic ammonia-oxidizing archaea from marine sediments in coculture with sulfur-oxidizing bacteria. Appl. Environ. Microbiol. 76, 7575-7587.

Pearson, A., McNichol, A.P., Benitez-Nelson, B.C., Hayes, J.M., Eglinton, T.I., 2001a Origins of lipid biomarkers in Santa Monica Basin surface sediment: a case study using compound-specific $\delta^{14} \mathrm{C}$ analysis. Geochim. Cosmochim. Acta 65 3123-3127.

Pitcher, A., Hopmans, E.C., Mosier, A.C., Park, S.-J., Rhee, S.-K., Francis, C.A. Schouten, S., Sinninghe Damsté, J.S., 2011. Core and intact polar glycerol dibiphytanyl glycerol tetraether lipids of ammonia-oxidizing Archaea enriched from marine and estuarine sediments. Appl. Environ. Microbiol. 77, 3468-3477.

Schmitz, B., Peucker-Ehrenbrink, B., Heilmann-Clausen, C., Åberg, G., Asaro, F., Lee, C.-T.A., 2004. Basaltic explosive volcanism, but no comet impact, at the Paleocene-Eocene boundary: high-resolution chemical and isotopic records from Egypt, Spain and Denmark. Earth Planet. Sci. Lett. 225, 1-17.

Schoon, P.L., Sluijs, A., Sinninghe Damsté, J.S., Schouten, S., 2011. Stable carbon isotope patterns of marine biomarker lipids in the Arctic Ocean during Eocene Thermal Maximum 2. Paleoceanography 26, PA3215, http://dx.doi.org/10.1029/ 2010PA002028.

Schoon, P.L., 2013 Impact of $\mathrm{CO}_{2}$ and $\mathrm{pH}$ on the Distribution and Stable Carbon Isotopic Composition of Microbial Biomarker Lipids (Ph.D. thesis), University of Utrecht, pp. 185. Available from: 〈http://igitur-archive.library.uu.nl/disserta tions/2013-0410-200505/UUindex.html

Schouten, S., Hoefs, M.J.L., Koopmans, M.P., Bosch, H.-J., Sinninghe Damsté, J.S. 1998. Structural characterization, occurrence and fate of archaeal ether-bound acyclic and cyclic biphytanes and corresponding diols in sediments. Org. Geochem. 29, 1305-1319.

Schouten, S., Hopmans, E.C., Pancost, R.D., Sinninghe Damsté, J.S., 2000. Widespread occurrence of structurally diverse tetraether membrane lipids: evidence for the ubiquitous presence of low-temperature relatives of hyperthermophiles. Proc. Natl. Acad. Sci. USA 97, 14421-14426.

Schouten, S., Middelburg, J.J., Hopmans, E.C., Sinninghe Damsté, J.S., 2010. Fossilization and degradation of intact polar lipids in deep subsurface sediments: a theoretical approach. Geochim. Cosmochim. Acta 74, 3806-3814.

Schouten, S., Hopmans, E.C., Sinninghe Damsté, J.S., 2013. The organic geochemistry of glycerol dialkyl glycerol tetraether lipids: a review. Org. Geochem. 54, 19-61.

Shah, S.R., Mollenhauer, G., Ohkouchi, N., Eglinton, T.I., Pearson, A., 2008. Origins of archaeal tetraether lipids in sediments: insights from radiocarbon analysis Geochim. Cosmochim. Acta 72, 4577-4594.

Sinninghe Damsté, J.S., Schouten, S., Hopmans, E.C., van Duin, A.C.T., Geenevasen, J. A.J., 2002. Crenarchaeol: the characteristic core glycerol dibiphytanyl glycerol tetraether membrane lipid of cosmopolitan pelagic crenarchaeota. J. Lipid Res. 43, 1641-1651.

Slotnick, B.S., Dickens, G.R., Nicolo, M.J., Hollis, C.J., Crampton, J.S., Zachos, J.C., Sluijs, A., 2012. Large-amplitude variations in carbon cycling and terrestrial weathering during the latest Paleocene and earliest Eocene: the record at Mead Stream, New Zealand. J. Geol. 120, 487-505.

Sluijs, A., Schouten, S., Donders, T.H., Schoon, P.L., Röhl, U., Reichart, G.J., Sangiorgi, F., Kim, J.-H., Sinninghe Damsté, J.S., Brinkhuis, H., 2009. Warm and wet conditions in the Arctic region during Eocene Thermal Maximum 2. Nat Geosci. 2, 777-780.

Sluijs, A., Dickens, G.R., 2012. Assessing offsets between the $\delta^{13} \mathrm{C}$ of sedimentary components and the global exogenic carbon pool across Early Paleogene carbon cycle perturbations. Global Biogeochem. Cycles 26, GB4005.

Stap, L., Lourens, L.J., Thomas, E., Sluijs, A., Bohaty, S., Zachos, J.C., 2010. Highresolution deep-sea carbon and oxygen isotope records of Eocene Thermal Maximum 2 and H2. Geology 38, 607-610.

Stein, R., Boucsein, B., Meyer, H., 2006. Anoxia and high primary production in the Paleogene central Arctic Ocean: first detailed records from Lomonosov Ridge. Geophys. Res. Lett. 33, L18606.

Summons, R.E., Franzmann, P.D., Nichols, P.D 1998, Carbon isotopic fractionation associated with methylotrophic methanogenesis. Org. Geochem. 28, 465-475.

Svensen, H., Planke, S., Malthe-Sørenssen, A., Jamtveit, B., Myklebust, R., Rasmussen Eidem, T., Rey, S., 2004. Release of methane from a volcanic basin as a mechanism for initial Eocene global warming. Nature 429, 542-545.

Westerhold, T., Röhl, U., McCarren, H.K., Zachos, J.C., 2009. Latest on the absolute age of the Paleocene-Eocene Thermal Maximum (PETM): new insights from exact stratigraphic position of key ash layers +19 and-17. Earth Planet. Sci. Lett. 287, 412-419.

Wuchter, C., Schouten, S., Boschker, H.T.S., Sinninghe Damsté, J.S., 2003. Bicarbonate uptake by marine Crenarchaeota. FEMS Microbiol. Lett. 219, 203-207.

Wuchter, C., Abbas, B., Coolen, M.J.L., Herfort, L., Timmers, P., Strous, M., Van Bleijswijk, J., Teira, E., Herndl, G.J., Middelburg, J.J., Schouten, S., Sinninghe Damsté, J.S., 2006. Archaeal nitrification in the ocean. Proc. Natl. Acad. Sci. USA 103, 12317-12322.

Zachos, J., Pagani, M., Sloan, L., Thomas, E., Billups, K., 2001. Trends, rhythms, and aberrations in global climate 65 Ma to present. Science 292, 686-693.

Zachos, J.C., Röhl, U., Schellenberg, S.A., Sluijs, A., Hodell, D.A., Kelly, D.C., Thomas, E. Nicolo, M., Raffi, I., Lourens, L.J., McCarren, H., Kroon, D., 2005. Rapid acidification of the ocean during the Paleocene-Eocene thermal maximum. Science 308, 1611-1615. 